\title{
PENGARUH MODEL PEMBELAJARAN ROLE PLAYING TERHADAP KETERAMPILAN BERBICARA SISWA KELAS V SD NEGERI SUKASARI II KABUPATEN TANGERANG
}

\author{
Elisa Deliyana $^{1}$, Hamdah Siti Hamsanah Fitriani ${ }^{2}$ \\ Universitas Muhammadiyah Tangerang \\ elisadeliyana@gmail.com ${ }^{I}$ \\ vitrianivit@gmail.com ${ }^{2}$
}

\begin{abstract}
ABSTRAK
Penelitian ini merupakan jenis penelitian eksperimen yang bertujuan untuk mengetahui pengaruh yang menggunakan model pembelajaran role playing terhadap keterampilan berbicara. Penelitian menggunakan metode penelitian quasi eksperimental desain penelitian Nonequivalent Control Group Design. Subjek populasi dalam penelitian ini adalah seluruh siswa kelas V SD Negeri Sukasari II Kabupaten Tangerang yang berjumlah 60 siswa, dengan mengambil sampel sebanyak 60 siswa yaitu kelas VA yang berjumlah 30 siswa sebagai kelas eksperimen dan kelas VB yang berjumlah 30 siswa sebagai kelas kontrol. Instrumen yang digunakan adalah tes lisan, yaitu pretes dan postes pada kelas kontrol dan kelas eksperimen. Hal tersebut dilakukan dengan menggunakan model The Separate Model T-Tes yaitu uji-t pretes menunjukkan $\mathrm{t}_{\text {hitung }} 1,58<\mathrm{t}_{\text {tabel }} 1,67$, maka disimpulkan bahwa tidak terdapat perbedaan yang signifikan antara rata-rata nilai pretes kelas kontrol dan kelas eksperimen. Sedangkan untuk pengujian hipotesis postes dari hasil uji $t$ diperoleh $t_{\text {hitung }} 7,85>t_{\text {tabel }} 1,67$,maka dapat disimpulkan terdapat perbedaan yang signifikan antara rata-rata nilai postes kelas kontrol dan kelas eksperimen. Hal ini dapat diartikan bahwa terdapat pengaruh model pembelajaaran role playing terhadap keterampilan berbicara siswa pada kelas V SD Negeri Sukasari II Kabupaten Tangerang.
\end{abstract}

Kata Kunci : Role Playing, Keterampilan Berbicara

\section{A. PENDAHULUAN}

Pendidikan merupakan usaha sadar yang dilakukan siswa untuk membantu meningkatkan perkembangan siswa agar memiliki kepribadian yang baik, cerdas, berakhlak mulia, dan berketerampilan yang diperlukan oleh dirinya dan masyarakat. Untuk itu, pendidikan harus berkualitas. Kegiatan pembelajaran siswa harus mengalami proses pembelajaran secara efektif dan bermakna. Perwujudan pembelajaran yang bermakna salah satunya dilihat dari perubahan tingkah laku siswa dalam kegiatan pembelajaran baik berupa sikap, pengetahuan, dan keterampilan. Pembelajaran harus sesuai dengan tujuan dan sasaran pendidikan. Pendidikan dapat diperoleh melalui lembaga formal, mulai dari jenjang anakanak sampai universitas, sementara pendidikan non formal dapat diperoleh dari lingkungan keluarga dan masyarakat.

Pembelajaran Bahasa Indonesia diharapkan mampu meningkatkan kemampuan berkomunikasi siswa dalam menggunakan Bahasa Indonesia yang baik secara tertulis maupun 
lisan. Bahasa Indonesia juga sebagai modal dasar siswa dalam mempelajari hal-hal yang ada di sekitarnya. Keterampilan berbahasa memiliki 4 aspek yang harus dikuasai oleh siswa, yaitu (1) Menyimak, (2) Berbicara, (3) Membaca dan (4) Menulis. Keterampilan berbahasa tersebut saling berkaitan satu sama lain. Keterampilan berbicara merupakan salah satu aspek yang harus dikembangkan dalam dunia pendidikan, siswa dilatih agar mampu menggunakan dan mengekspresikan gagasan dan pemikirannya dengan menggunakan kata dan kalimat yang baik dan tepat. Seseorang yang memiliki keterampilan berbicara yang baik akan mudah bergaul dengan orang yang disekelilingnya dan mampu menyampaikan pesan disampaikan dapat berjalan dengan baik.

Keterampilan berbicara memiliki peranan yang penting pada setiap pembelajaran, karena setiap pembelajaran siswa diharapkan mampu berkomunikasi dengan baik agar proses pembelajaran dapat berlangsung sesuai dengan yang diharapkan. Semua orang dapat berbicara, namun tidak semua orang dapat terampil berbicara dengan baik. Keterampilan berbicara harus dikuasai oleh setiap siswa. Menurut Musaba (2012:7), keterampilan berbicara adalah salah satu wujud kemampuan berbahasa, disamping kemampuan menyimak, kemampuan membaca, dan kemampuan menulis. Keterampilan berbicara merupakan keterampilan yang perlu dibelajarkan dengan melakukan praktik langsung sehingga siswa benar-benar bisa mengasah alat ucapnya agar dapat menyampaikan ejaan yang baik dan benar. Selain itu, keterampilan juga mampu melahirkan generasi masa depan yang cerdas, aktif, kreatif, kritis dan berbudaya. Masa depan yang kritis karena mereka memiliki kemampuan untuk mengekspresikan gagasan, pikiran, atau perasaan kepada orang lain secara sistematis.

Berdasarkan hasil observasi yang peneliti lakukan di kelas V SD Negeri Sukasari II Kabupaten Tangerang menunjukkan bahwa masih rendahnya tingkat keterampilan berbicara siswa kelas V. Selama ini kurangnya penggunaan model-model pembelajaran yang efektif dalam kegiatan belajar mengajar sehingga tidak adanya ketertarikan siswa dalam pelajaran Bahasa Indonesia khususnya keterampilan berbicara, karena cara penyampaian guru kurang menarik dan proses pembelajarannya monoton guru hanya menerangkan materi saja tidak memberikan kesempatan siswa untuk ikut aktif menyampaikan ide gagasannya. Keterampilan yang diperoleh hanya terfokus pada teori saja dari pada praktik. Hal tersebut mengakibatkan siswa kurang terlatih untuk mengasah alat ucapnya dan mengungkapkan pendapatnya. Selain itu, saat berbicara siswa juga belum dapat menggunakan Bahasa Indonesia yang baik dan benar akhirnya pada saat siswa diminta untuk berbicara didepan kelas terlihat banyaknya siswa yang masih malu-malu, kurang percaya diri, dan grogi. Siswa juga belum menguasai 
faktor-faktor kebahasaan, seperti ketepatan ucapan, intonasi, dan pemilihan kata yang kurang tepat. Kesalahan ini terjadi sudah terbiasa mengucapkan bunyi bahasa yang kurang tepat dan tidak ada yang memperbaikinya sehingga keterampilan berbicara siswa menjadi rendah.

Permasalahan yang telah dijelaskan sebelumnya perlu diatasi dengan memberikan kesempatan kepada siswa untuk melatih keterampilan berbicara siswa melalui model pembelajaran Role Playing. Model pembelajaran Role Playing adalah model pembelajaran bermain peran yang membimbing peserta didik untuk melakukan kegiatan memainkan peran seperti yang didapat melalui kehidupan nyata dengan tujuan untuk melatih kecakapan melalui bermain peran. Model pembelajaran Role Playing ini sangat cocok diterapkan dalam pembelajaran Bahasa Indonesia khususnya materi bermain peran karena dalam model pembelajaran Role Playing ini siswa dilibatkan secara aktif dalam proses pembelajaran dan langsung mempraktikannya sehingga siswa bisa mengasah alat ucapnya dan guru dapat mengetahui penguasaan faktor-faktor kebahasaan, seperti ketepatan ucapan dan pemilihan kata yang kurang tepat.

Oleh karena itu peneliti berasumsi bahwa penggunaan model pembelajaran Role Playing dapat berpengaruh terhadap keterampilan berbicara siswa. Berdasarkan uraian yang telah dipaparkan, maka peneliti tertarik untuk melakukan penelitian dengan judul Pengaruh Model Pembelajaran Role Playing Terhadap Keterampilan Berbicara Siswa Kelas V SD Negeri Sukasari II Kabupaten Tangerang.

\section{B. KAJIAN TEORI}

Keterampilan berbicara merupakan proses penting dalam kehidupan seseorang. Berbicara adalah komunikasi langsung dengan memanfaatkan saluran lisan sebagai bahasa simbol yang dihasilkan oleh alat ucap manusia. Keterampilan berbicara merupakan keterampilan mengucapkan bunyi-bunyi atau mengungkapkan gagasan dan pikirannya. Setiap gagasan dan pemikiran-pemikiran yang dihasilkan oleh setiap individu dalam proses pembelajaran akan lebih mudah disampaikan dengan cara berbicara apalagi dengan keterampilan berbicara yang baik. Menurut Tarigan (2008:3), keterampilan berbicara adalah kemampuan mengucapkan bunyi-bunyi suatu keterampilan berbahasa yang berkembang pada kehidupan anak, yang hanya didahului oleh keterampilan menyimak, dan pada masa tersebutlah kemampuan berbicara atau berujar dipelajari. Dari pendapat Tarigan dapat diperoleh informasi bahwa keterampilan berbicara adalah suatu keterampilan berbahasa yang dilakukan dengan cara berbicara dengan menggunakan bahasa lisan sehingga maksud tersebut mudah dipahami oleh orang lain dengan tujuan agar dapat melatih keterampilan dalam kecakapan berbicara. 
Adapun menurut Nurjamal, dkk (2011:4), keterampilan berbicara adalah keterampilan berikutnya yang kita kuasai setelah kita menjalani proses latihan belajar menyimak serta kemampuan seseorang untuk mengungkapkan gagasan, pikiran, perasaan secara lisan kepada orang lain. Dengan demikian penulis berpendapat bahwa keterampilan berbicara adalah kemampuan individu dalam berkomunikasi mengungkapkan segala ide, gagasan, pikiran sebagai proses komunikasi kepada seseorang dengan menggunakan bahasa lisan sehingga maksud tersebut dipahami oleh orang lain. Berdasarkan penjelasan dari pendapat Musaba dapat dikatakan bahwa keterampilan berbicara adalah wujud dari keterampilan berbahasa yang mencakup beberapa aspek selain kemampuan menyimak, menulis dan membaca.

Setiap kegiatan pembelajaran, guru memerlukan unsur-unsur pendukung guna membantu dalam melakukan kegiatan pembelajaran agar pembelajaran menjadi lebih menyenangkan dan sesuai dengan tujuan pembelajaran yang akan dicapai. Unsur-unsur pendukung tersebut salah satunya adalah model pembelajaran. Untuk menciptakan suasana pembelajaran yang menyenangkan dan efektif guru harus memiliki berbagai keterampilan pembelajaran, salah satunya yang berkaitan dengan model pembelajaran. Model pembelajaran adalah bentuk pembelajaran yang disajikan oleh pendidik dengan tujuan agar kegiatan belajar mengajar dapat berjalan dengan baik.

Sebagai seorang pendidik, pendidik harus mampu menguasai berbagai macam modelmodel pembelajaran yangdapat digunakan dalam proses kegiatan pembelajaran. Model pembelajaran yang baik adalah model pembelajaran yang cocok digunakan dalam setiap pembelajaran. Terdapat berbagai macam model-model pembelajaran, salah satunya adalah model pembelajaran Role Playing. Model pembelajaran Role Playing adalah model pembelajaran bermain peran dengan memberikan kesempatan kepada siswa untuk ikut aktif berperan dalam memainkan peranan lakon sesuai dengan kelompoknya bertujuan untuk melatih siswa agar memiliki keterampilan berbicara yang baik. Menurut Shoimin (2014:16), model Role Playing adalah model yang memberikan kesempatan kepada siswa untuk praktik menempatkan diri mereka dalam peran-peran dan situasi-situasi yang akan meningkatkan kesadaran terhadap nilai-nilai dan keyakinan-keyakinan mereka sendiri dan orang lain. Model pembelajaran Role Playing adalah model pembelajaran yang dapat memberikan kesempatan kepada siswa untuk memerankan lakon dalam situasi-situasi yang dapat meningkatkan kesadaran tentang nilai dan keyakinan yang ada dimasyarakat.

Selanjutnya menurut Priansa (2017:192), model Role Playing adalah model bermain peran yang dirancang khusus untuk membantu peserta didik memahami nilai-nilai sosial dan moral melalui serangkaian perilaku. Model Role Playing dikatakan sebagai model 
pembelajaran yang dapat memberikan kesempatan kepada peserta didik untuk membantu peserta didik agar memahami nilai-nilai sosial dan moral dengan cara bermain peran memerankan serangkaian perilaku. Saefuddin (2015:133), berpendapat model Role Playing adalah model yang mendramatisasikan cara bertingkah laku dalam hubungan sosial dengan peserta didik diikutsertakan dalam memainkan peran dalam dramatisasi tersebut (h. 133). Dapat dikatakan model Role Playing adalah cara peserta ikut aktif dalam kegiatan pembelajaran dengan cara bertingkah laku dengan memainkan peran dalam hubungan sosial. Berdasarkan pendapat dari para ahli yang telah diuraikan, dapat disimpulkan bahwa model Role Playing adalah model pembelajaran yang dapat memberikan kesempatan kepada peserta didik untuk ikut aktif dalam kegiatan pembelajaran memerankan lakon dalam situasi-situasi yang dapat meningkatkan kesadaran tentang keyakinan agar memahami nilai sosial dan moral dalam kehidupan masyarakat.

Model ini dilakukan dengan langkah-langkah model pembelajaran Role Playing sebagai berikut: 1. Guru menyusun/menyiapkan skenario yang akan ditampilkan, 2. Guru menceritakan kepada siswa tentang materi yang akan dibahas dalam pembelajaran, 3. Guru membentuk kelompok siswa yang anggotanya 5 orang, 4. Siswa diberi waktu untuk mempelajari drama pendek, 5. Guru meminta masing-masing kelompok untuk melakonkan skenario yang sudah dipersiapkan, 6. Masing-masing kelompok memperhatikan skenario yang sedang diperagakan oleh kelompok lain, 7. Setelah dipentaskan, masing-masing kelompok diberikan kesempatan untuk mengomentari peranan lakon yang diperagakan oleh kelompok lain, 8. Masing-masing kelompok menyampaikan hasil kesimpulannya, 9. Evaluasi, 10. Penutup.

\section{METODE PENELITIAN}

Metode penelitian yang digunakan dalam penelitian ini adalah metode penelitian eksperimen (kuantitatif). Metode penelitian eksperimen yaitu metode penelitian yang digunakan untuk mencari pengaruh perlakuan tertentu terhadap yang lain dalam kondisi yang terkendalikan (Sugiyono, 2016:72). Metode ini menggunakan desain Quasi Experimental Design dalam penelitian eksperimen ini hampir sama dengan Tru Experimen, perbedaannya terletak pada penentuan sampel yang tidak dipilih secara acak (random).

Desain yang digunakan yaitu bentuk Nonequivalent Control Group Design. Dalam penelitian ini sampel akan dibagi menjadi 2 dan diberi perlakuan yang berbeda yang bertujuan untuk mengetahui ada tidaknya perbedaan keterampilan berbicara siswa kelas V SD yang diajarkan dengan model pembelajaran Role Playing di SD Negeri Sukasari II Kabupaten Tangerang. Sehingga subjek penelitian dibagi menjadi kelompok eksperimen dan kelompok 
kontrol. Pada kelas eksperimen diberi perlakuan berupa model Role Playing dan kelompok kontrol adalah kelompok siswa yang tidak diberi perlakuan model Role Playing. Kemudian kedua kelas tersebut diberikan pretes untuk mengetahui keadaan awal apakah ada perbedaan antara kelas eksperimen dan kelas kontrol. Sehingga desain penelitian ini dapat ditampilkan pada tabel 3.2 sebagai berikut

Tabel 3.1 Nonequivalent Control Group Design

\begin{tabular}{|l|l|l|l|}
\hline Kelompok & Pretes & Perlakuan & Postes \\
\hline Eksperimental & $\mathbf{Y}_{\mathbf{e}}$ & $\mathbf{X}$ & $\mathbf{Y}_{\mathbf{e}}$ \\
\hline Kontrol & $\mathbf{Y}_{\mathbf{k}}$ & - & $\mathbf{Y}_{\mathbf{k}}$ \\
\hline
\end{tabular}

(Riadi, 2015, h. 14)

Keterangan :

$\mathrm{Y}_{\mathrm{e}} \quad=$ Data hasil petes kelas eksperimental

$\mathrm{Y}_{\mathrm{e}} \quad=$ Data hasil postes kelas eksperimental

$\mathrm{Y}_{\mathrm{k}} \quad=$ Data hasil pretes kelas kontrol

$\mathrm{Y}_{\mathrm{k}} \quad=$ Data hasil postes kelas kontrol

$\mathrm{X}=$ perlakuan yang diberikan pada kelas eksperimen

\section{PEMBAHASAN}

Penelitian ini menggunakan metode kuantitatif yaitu dengan menggunakan statistik dari hasil observasi untuk mengetahui peningkatan hasil belajar keterampilan berbicara pada drama kelas $\mathrm{V}$ dengan menggunakan model pembelajaran role playing. Pembahasan hasil penelitian ini untuk menunjukkan jawaban semua permasalahan dalam penelitian yaitu untuk mengetahui hasil belajar siswa terhadap keterampilan berbicara.

Berdasarkan hasil perhitungan penelitian data pretes dari kelas eksperimen dan kelas kontrol menggunakan uji T menunjukkan bahwa kemampuan awal peserta didik kedua kelas tersebut dalam keterampulan berbicara tidak berbeda secara signifikansi 5\% $(\alpha=0,05)$. Hasil analisis diperoleh rata-rata pretes kelas eksperimen 54,23, rata-rata kelas kontrol 52,9, standar deviasi pretes kelas eksperimen $(12,49)=156,02$ dan standar deviasi pretes kelas kontrol $(10,41)=108,37 t_{\text {hitung }} 1,58<t_{\text {tabel }} 1,67$ artinya $t_{\text {hitung }}$ lebih kecil dibandingkan $t_{\text {tabel }}$, ini menunjukkan bahwa tidak terdapat perbedaan yang signifikan terhadap keterampilan berbicara pada drama antara kelas eksperimen dan kelas kontrol. Hal ini disebabkankan karena belum adanya proses penerapan model pembelajaran atau perlakuan yang diberikan kelas eksprerimen maupun kontrol. 
Setelah diberikan perlakuan dalam kegiatan pembelajaran yaitu pada kelas eksperimen dengan model pembelajaran Role Playing dan kelas kontrol diberikan pembelajaran dengan model pembelajaran konvensional. Sehingga diperoleh data postes atau tes akhir dengan menggunakan uji $T$, memberikan hasil bahwa peserta didik yang diberikan model pembelajaran role playing lebih mengalami peningkatan dibanding dengan siswa yang diajarkan dengan model pembelajaran biasa atau konvensional. Hal ini dapat dilihat dari analisis yang diperoleh rata-rata postes kelas eksperimen 64,83 , rata-rata kelas kontrol 58,23, standar deviasi postes kelas eksperimen $(13,13)=172,53$ dan standar deviasi postes kelas kontrol $(10,69)=114,45 t_{\text {hitung }} 7,85>t_{\text {tabel }} 1,67$ artinya $t_{\text {hitung }}$ lebih besar dibandingkan $t_{\text {tabel }}$, ini menunjukkan bahwa terdapat perbedaan keterampilan berbicara antara siswa yang diberi model pembelajaran Role Playing dengan siswa yang diberi model pembelajaran konvensional.

Dari hasil pengujian di atas diperoleh bahwa rata-rata keterampilan berbicara pada drama yang mendapatkan pembelajaran dengan model pembelajaran Role Playing lebih tinggi dibandingkan dengan keterampilan berrbicara siswa yang mendapatkan pembelajaran dengan menggunakan model pembelajaran konvensional. Pembelajaran yang dilakukan pada kelas eksperimen yang menggunakan model pembelajaran Role Playing meningkatkan keterampilan berbicara siswa. Hal itu terlihat dari kelancaran siswa dalam mengutarakan pendapatnya dalam bermain peran karena model pembelajaran Role Playing ini adalah model pembelajaran yang bertujuan untuk melatih kecapakan dalam berbicara. Sehingga pembelajaran di kelas eksperimen ini menunjukan ketertarikan siswa terhadap pembelajaran drama yang menggunakan model pembelajaran Role Playing, karena pada setiap pertemuan siswa kelas eksperimen diberikan praktik bermain peran dan pada sesudah perlakuan siswa diberikan jalan cerita yang harus diperankan oleh para siswa yang ditunjuk untuk bermain peran serta siswa yang lain dituntut untuk mengomentari, sehingga siswa lebih aktif dalam mengutarakan pendapatnya serta dapat melatih kecapakannya dalam berbicara

Sedangkan pada kelas kontrol adalah pembelajaran konvensional. Selama proses pembelajaran berlangsung setiap pertemuan peneliti hanya menyampaikan materi pembelajaran dari awal sampai akhir, sedangkan siswa hanya mendengarkan dan mencatat. Ketika peneliti memberikan tugas untuk mempraktikan, siswa hanya melakukan praktik semampu mereka tanpa ada rangsang yang diberikan oleh peneliti seperti pada kelas eksperimen yang diberikan sebuah tugas untuk mengomentari dan memberikan saran pada saat siswa bermain peran. Proses pembelajaran yang demikian mengakibatkan keterampilan berbicara siswa rendah. Dengan demikian, hasil penelitian ini menunjukkan bahwa terdapat 
perbedaan keterampilan berbicara antara siswa yang diberi model pembelajaran role playing dengan siswa yang diberi metode konvensional.

\section{E. SIMPULAN DAN SARAN}

Berdasarkan hasil penelitian dapat disimpulkan bahwa hasil instrumen yang digunakan dengan model pembelajaran role playing berpengaruh terhadap keterampilan berbicara siswa SD Negeri Sukasari II Kabupaten Tangerang. Perhitungan postes terdapat rata-rata kelas eksperimen dan kelas kontrol, hasil uji normalitas menunjukkan bahwa data berdistribusi normal dan hasil uji normalitas menunjukkan bahwa varian data adalah homogen. Hal ini dapat dilihat dari hasil hipotesis yaitu pretes pada kelas eksperimen dan kelas kontrol $\mathrm{H}_{0}$ diterima $\mathrm{H}_{1}$ ditolak, maka dapat disimpulkan bahwa $\mathrm{t}_{\text {hitung }}=1,58<\mathrm{t}_{\text {tabel }} 1,67$ maka pretes tidak memiliki perbedaan hasil belajar yang signifikan, sedangkan hasil postes kelas eksperimen dan kelas kontrol yaitu $\mathrm{H}_{1}$ diterima $\mathrm{H}_{0}$ ditolak 7,85 $>\mathrm{t}_{\text {tabel }} 1,67$, maka dapat disimpulkan bahwa pemberian postes pada kelas eksperimen dan postes pada kelas kontrol yang tidak dapat mendapat perlakuan dengan menggunakan model role playing menunjukkan hasil yang sangat signifikan.

Meningkatnya keterampilan berbicara pada bermain peran siswa tidak lepas dari ketercapaian indikator pembelajaran. Hasil pembelajaran di kelas yang menggunakan model pembelajaran role playing berlangsung baik dan memacu siswa dapat terlibat secara aktif dalam proses pembelajaran hal ini dapat dilihat dari cara siswa berani dalam mengungkapkan pendapatnya sehingga keterampilan berbicara siswa siswa kelas V meningkat. Dengan demikian model pembelajaran role playing berjalan dengan baik dan berhasil.

Berdasarkan pembahasan dan simpulan di atas, peneliti memiliki saran yaitu 1) model pembelajaran ini dapat memberikan pengalaman yang mengesankan karena siswa langsung dilibatkan secara aktif dalam pembelajaran sehingga menjadi lebih aktif dan menyenangkan, 2) peneliti menyarankan sebaiknya guru Bahasa Indonesia hendaknya lebih baik dalam memilih model-model pembelajaran dalam mempelajari keterampilan berbicara siswa agar siswa tidak merasa jenuh ketika mengikuti pembelajaran di kelas, 3) model pembelajaran role playing terbukti mampu meningkatkan keterampilan berbicara pada materi bermain peran. Oleh karena itu, sebaiknya guru Bahasa Indonesia dapat menjadikan model pembelajaran role playing sebagai salah satu model pembelajaran yang dapat digunakan untuk meningkatkan keterampilan berbicara siswa. 
Lingua Rima: Jurnal Pendidikan Program Studi Bahasa dan Sastra Indonesia

Vol. 8 No. 1 Januari 2019

\section{F. DAFTAR PUSTAKA}

Musaba, Z. (2012). Terampil Berbicara Teori dan Pedoman Penerapannya. Yogyakarta : CV Aswaja Pressindo.

Nurjamal, D \& Warta S. (2017). Terampil Berbahasa. Bandung : Alfabeta.

Priansa, D.J. (2017). Pengembangan Strategi dan Model Pembelajaran. Bandung:CV Pustaka Setia.

Riadi, E. (2015). Metode Statistika Parametrik dan Nonparametrik. Tangerang: Pustaka Mandiri.

Saefuddin, A \& Ika B. (2015). Pembelajaran Efektif. Bandung: PT Remaja Rosdakarya.

Sugiyono. (2015). Metode Penelitian Kuantitatif, Kualitatif, Rnd. Bandung: Alfabeta.

Shoimin, A. (2014). 68 Model Pembelajaran Inovatif dalam Kurikulum 2013. Yogyakarta : AR-ruzz Media.

Tarigan, H.G. (2008). Berbicara sebagai Suatu Keterampilan Berbahasa. Bandung : Angkasa. 